\title{
Against Covert A-Movement in Russian Unaccusatives
}

\section{Citation}

Polinsky, Maria and Eric Potsdam. 2011. Against covert A-movement in Russian unaccusatives. Linguistic Inquiry 42(2): 345-355.

\section{Published Version}

doi:10.1162/LING_a_00045

\section{Permanent link}

http://nrs.harvard.edu/urn-3:HUL.InstRepos:4906817

\section{Terms of Use}

This article was downloaded from Harvard University's DASH repository, and is made available under the terms and conditions applicable to Open Access Policy Articles, as set forth at http:// nrs.harvard.edu/urn-3:HUL.InstRepos:dash.current.terms-of-use\#OAP

\section{Share Your Story}

The Harvard community has made this article openly available.

Please share how this access benefits you. Submit a story.

\section{Accessibility}




\section{Against covert A-movement in Russian unaccusatives ${ }^{I}$}

\section{$1 \quad$ Introduction}

It is widely accepted that there are displacement operations which show no visible phonological reflex. We use the term COVERT MOVEMENT to refer to such operations. Covert movement has been at the forefront of the Principles and Parameters research agenda since Huang 1982 and May 1985, which used it to account for Chinese wh-in-situ and English quantified noun phrases, respectively. In the domain of A'-movement, there are covert analogues of most overt movement phenomena, including covert whmovement (Huang 1982, Richards 2001) and covert scrambling (e.g. Mahajan 1990). Within the domain of A-movement however, the picture is rather different. Overt Amovement phenomena such as subject-to-subject raising, passive, and unaccusative advancement are robustly attested cross-linguistically; however, clear cases of covert Amovement are rare. One instance proposed in the literature is Babyonyshev et al.'s (2001) covert A-movement analysis of Russian unaccusatives. In this squib, we revisit that material and argue against the covert A-movement analysis on empirical grounds. We conclude that Russian unaccusatives do not instantiate covert A-movement.

\footnotetext{
${ }^{1}$ Abbreviations: ACC—accusative, COMP—complementizer, GEN—genitive, GN— genitive of negation, IMF - imperfective, INF - infinitive, MASC - masculine, NEGnegation, NOM-nominative, NTR—neuter, PERF-perfective, PL—plural, PRESpresent, SBJV—subjunctive.
} 


\section{The argument for covert A-movement in Russian (Babyonyshev et al. 2001)}

The A-movement that Babyonyshev et al. (2001) investigates is the movement of the internal argument of an unaccusative predicate to subject position. In English, the theme of an unaccusative predicate begins as an internal argument and moves overtly to the subject position, (1) (Perlmutter 1978, Pesetsky 1982, Burzio 1986, Levin and Rappaport Hovav 1995). In some languages, such as Italian, this movement is optional (Perlmutter 1983, Burzio 1986 and others).

(1) $\quad[$ TP snow $[$ vp melted snow $]]$

Russian has several unaccusativity diagnostics (Chvany 1975, Pesetsky 1982), among them the Genitive of Negation (GN). GN is a phenomenon in which an underlying direct object may appear in the genitive case when licensed by negation. To illustrate, the genitive of the direct object in (2a) is impossible because there is no negation but, in the negative (2b), the accusative and the genitive alternate.

(2) a. ja uvidel ptic-u/*ptic-y

1SG saw bird-ACC/*bird-GEN

'I saw a/the bird.' (GN impossible)

b. ja ne uvidel ptic-u/ptic-y

$1 \mathrm{SG}$ not saw bird-ACC/bird-GEN

'I did not see a/any/the bird.' (GN possible)

GN is impossible on subjects of transitive verbs, (3), and some intransitive verbs, (4), even in the presence of negation:

(3) a. ni-kak-ie máčik-i ne polučili podarki

NEG-kind-NOM.PL boy-NOM.PL not received gifts 
b. *ni-kak-ix mal'čik-ov ne polučilo podarki

NEG-kind-GEN.PL boy-GEN.PL not received gifts

'No boys received gifts.'

(4) a. ni-kak-ie devočk-i ne tancevali

NEG-kind-NOM.PL girl-NOM.PL not danced

b. *ni-kak-ix devoček ne tancevalo

NEG-kind-GEN.PL girl-GEN.PL not danced

'No girls/None of the girls were dancing.'

In contrast, GN is possible with subjects of intransitive verbs that are canonically analyzed as unaccusatives. In this case, GN alternates with the nominative. We illustrate this alternation with the subject of a simple unaccusative verb, (5); the alternation is also possible on subjects of passive verbs and raising verbs. ${ }^{2}$

a. ni-kak-ie grib-y zdes' ne rast-ut

NEG-kind-NOM.PL mushroom-NOM.PL here not grow-PRES.3PL

b. zdes' ne rast'-ot ni-kak-ix grib-ov

here not grow-PRES.SG NEG-kind-GEN.PL mushroom-GEN.PL

'No mushrooms/None of the mushrooms grow here.'

Generalizing over this data and others, Babyonyshev et al. proposes the following conditions on GN licensing:

\footnotetext{
${ }^{2}$ In addition to the case difference, there is also a difference in agreement: verbal and adjectival predicates agree with the nominative but verbs and adjectives assume default agreement with the genitive.
} 
(6) a. GN only appears on underlying direct objects (Babyonyshev et al. (7))

b. GN is licensed by negation under m-command

c. GN is licensed across infinitival clause boundaries

d. GN on a DP must be licensed at the DP's highest position in an A-chain

e. GN licensing is checked at LF

Babyonyshev et al. assign the following derivation to the GN example in (5b).

$$
\begin{array}{clrlll}
\text { [тр nikakix } & \text { gribor } & \text { zdes' } & \text { ne [vp rast'ot nikakix } & \text { gribov]] } \\
\text { kind } & \text { mushrooms here } & \text { not } & \text { grown kind.GEN } & \text { mushroom.GEN.PL }
\end{array}
$$

'No mushrooms grow here.'

On the surface, the GN is in the direct object position. At LF, the GN moves to the matrix subject position, spec, TP. We represent this covert movement using a crossed out copy in the higher position. The highest link in the chain is licensed as required by (6) by being m-commanded by negation.

The argument for covert A-movement comes from the following claim: When an unaccusative verb is embedded under a raising verb, the genitive theme argument of that verb can be licensed by matrix negation, but not by embedded negation:

a. ne dolžno [pojavit'sja ni-kak-ix mal'čik-ov v klasse] not must.NTR appear.INF.PERF NEG-kind-GEN.PL boy-GEN.PL in class 'There don't have to appear any boys in class.' (B. et al., ex. (20a))

b. *dolžno [ne pojavit'sja ni-kak-ix mal'čik-ov $\mathrm{v}$ klasse $]$ must.NTR not appear.INF.PERF NEG-kind-GEN.PL boy-GEN.PL in class ('There must not appear any boys in class.') (B. et al., ex. (20b)) 
The GN in (8a) is licensed by matrix negation according to the licensing conditions in (6). Whether or not the GN moves to the matrix subject position, it will be m-commanded by the matrix negation. The ungrammaticality of (8b), in contrast, requires the following explanation: The GN undergoes covert A-movement to the matrix subject position yielding the LF in (9).

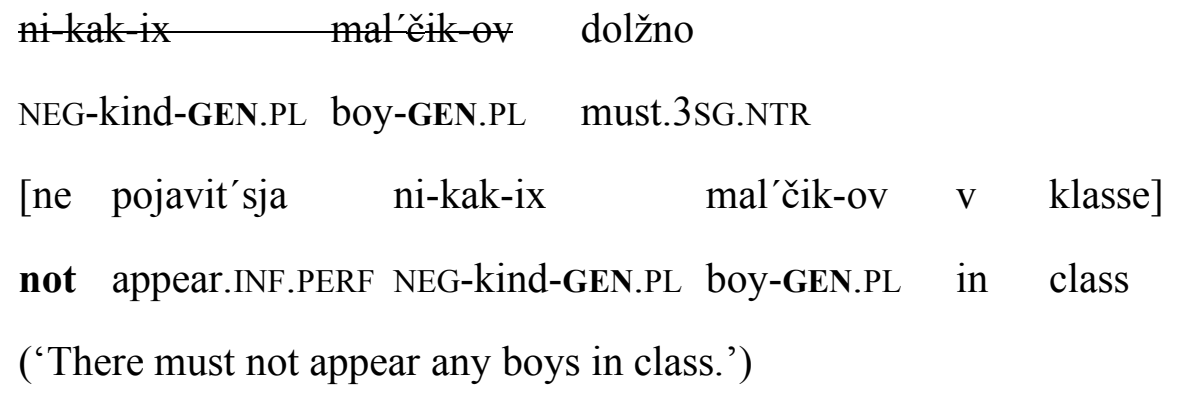

The embedded negation does not license GN because the GN has moved out of its mcommand domain at LF. The highest link in the A-chain is thus not licensed, in violation of (6d). If the GN were to not undergo covert A-movement, it should be licensed in its base position, contrary to fact, because it is m-commanded by the embedded negation. Thus, Babyonyshev et al. concludes that Russian unaccusatives instantiate covert Amovement.

\section{Evidence against covert A-movement in Russian}

The main argument against the covert A-movement analysis is empirical. The crucial example, (8b), is unacceptable for independent reasons not related to the licensing of GN. Structurally similar examples, with different lexical items, are fully acceptable. Three 
further arguments against covert A-movement come from coordination, long-distance scrambling, and scope. ${ }^{3}$

\subsection{Graded judgments: semantic and pragmatic factors}

Speakers' judgments on the crucial example, (8b), repeated as (10), vary depending upon several non-syntactic factors: aspect of the embedded verb, choice of raising verb, animacy of the theme, and word order. None of these factors individually makes such examples unacceptable; however, violating all four factors results in the significant degradation seen in $(8 b){ }^{4}$

To begin, speakers judge the example much more acceptable if the embedded verb is imperfective (all other items are held constant), (11). To quantify this difference, ten native speakers were asked to rate these two examples on a 1-5 scale, with 1 being completely unacceptable and 5 being fully acceptable. ${ }^{5}$ The example with the perfective had an average rating of 1.8 , while the example with the imperfective had an average of 3.75. Where relevant, additional judgments determined in this way are given below in

${ }^{3}$ Additional arguments, which we have omitted for lack of space, come from binding and control into gerund clauses.

${ }^{4}$ Some of the grammatical examples below are in fact non-optimal with respect to one or more of these factors. The degradation caused by the various factors is not linearly cumulative however, a result familiar from the literature on sentence processing (Keller 2001, among others).

${ }^{5}$ The native speakers' average age was 29. Seven speakers were interviewed in Russia; three other speakers, interviewed in the USA, had been in the country 1 or 2 years. 
square brackets. Changes to examples below from Babyonyshev et al.'s original example are glossed in bold face.

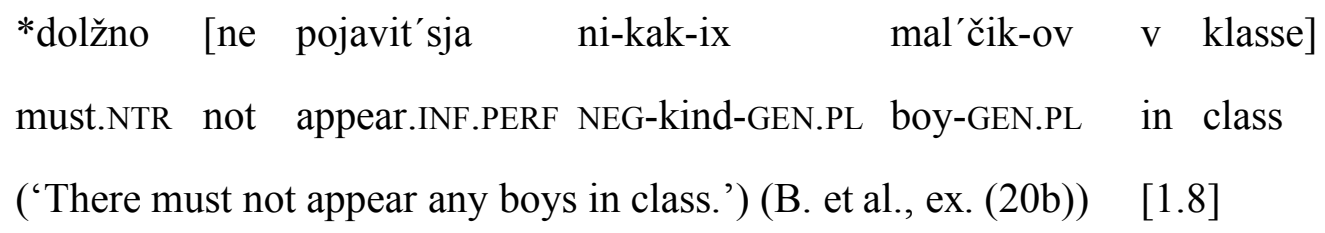

$$
\begin{aligned}
& \text { ?dolžno [ne pojavljat'sja ni-kak-ix mal'čik-ov } \mathrm{v} \text { klasse] } \\
& \text { must.NEUTER not appear.INF.IMF NEG-kind-GEN.PL boy-GEN.PL in class } \\
& \text { 'There must not appear any boys in class.' }
\end{aligned}
$$

From a syntactic perspective, this contrast is unexpected. Aspectual differences do not otherwise affect A-movement. For instance, passives in Russian form equally well with perfective and imperfective verbs. The alternative we would like to propose is nonsyntactic: the perfective aspect on the verb and the genitive on the internal argument in (10) are semantically mismatched. Slavic perfective typically entails completion and telicity; the imperfective does not have such entailments (Comrie, 1976, Filip 1999, Partee and Borschev 2007, and others). Turning now to the genitive, it differs from the cases it alternates with (the accusative and the nominative) in that it can denote a referent that is not at all or less affected by the event in question (Benigni 2006). This interpretation is more compatible with the general meaning of the imperfective (Pereltsvaig 1999 and references therein), and may be seen as conflicting with the perfective, which contributes to the reduced acceptability of the critical example.

The second relevant factor is the modality of the raising verb. Babyonyshev et al.'s example uses the deontic modal 'must'. With a different modal, the example becomes more acceptable even if the aspect remains perfective. We illustrate this improvement 
with the past tense modal, mogl- 'could' in (12). The average rating of 4.1 from native speakers should be contrasted with the 1.8 rating of Babyonyshev et al.'s example, (10).

$$
\begin{array}{llllll}
\text { moglo } \quad[\text { ne } & \text { pojavit'sja } & \text { ni-kak-ix } & \text { mal'čik-ov } & \text { v } & \text { klasse }] \\
\text { could.NTR not } & \text { appear.INF.PERF } & \text { NEG-kind-GEN.PL } & \text { boy-GEN.PL in } & \text { class }
\end{array}
$$$$
\text { 'There could have not appeared any boys in class.' }
$$

Again, this change in acceptability is unexpected under a purely syntactic analysis but looks reasonable if we take into consideration simple interpretive effects. The choice of the modal 'must' in Babyonyshev et al.'s original example predisposes the example towards a reading that is incompatible with unaccusative lexical semantics. Dolžno 'must' is often associated with a volitional agent or "performer", whereas subjects of unaccusatives are typically non-volitional (Dowty 1991, Levin and Rapaport Hovav 1995, Partee and Borschev 2007). This creates a semantic mismatch. There is no semantic conflict with the modal in (12), which does not have a bias towards volitionality, and the example become more acceptable.

If this explanation is on the right track, then we expect that the critical example will improve, even with the modal dolžno 'must', if we make the theme compatible with typical unaccusative semantics. One way to do this is to make the embedded theme inanimate. First, in such a case there is no possibility of interpreting the inanimate theme as a volitional entity bound by the obligation expressed by 'must'. Second, subjects of unaccusatives are more typically inanimate. (13) keeps the modal constant but changes the theme of the unaccusative from 'boys' to the inanimate 'difficulties', and the judgment improves significantly, from 1.8 to 4.0 . 


$$
\begin{array}{lllll}
\text { dolžno } \quad \text { ne } & \text { pojavit'sja ni-kak-ix } & \text { zatrudnen-ij } & \text { v klasse }] \\
\text { must.NTR not appear.INF.PERF } & \text { NEG-kind-GEN.PL } & \text { difficulty-GEN.PL in class } \\
\text { 'There must not appear any difficulties in class.' } & {[4.0]}
\end{array}
$$

The relevant examples in Babyonyshev et al. have animate themes with unaccusative verbs. This may contribute to their unacceptability but the source of that unacceptability is not syntactic.

If we look at the native speakers' judgments above, the judgments for the more acceptable examples hover around 4.0, still not reaching the higher end of the scale. We hypothesize that a final source for the reduced acceptability is word order. Although Russian word order is quite flexible, verb-initial orders are dispreferred outside of purely presentational structures (Babby 1975, 1980, Partee and Borschev 2002, 2007). If the relevant examples above begin with a scene-setting adverbial expression, their acceptability improves even further, even with the crucial example that Babyonyshev et al. relies on:

$$
\begin{aligned}
& \text { vo vremja vstuplenija na scene dolžno ni } \mathrm{v} \text { koem slučae } \\
& \text { in time introduction on stage must.NTR NEG in any case } \\
& \text { [ne pojavit'sja ni-kak-ix mal'čcik-ov] } \\
& \text { not appear.INF.PERF NEG-kind-GEN.PL boy-GEN.PL }
\end{aligned}
$$

'During the introduction there must absolutely not appear any boys on the stage.' [4.5]

The graded judgments can all be explained by taking into account semantics and information structure. The purely syntactic account is at best incomplete and at worst unnecessary since it cannot account for the variation. Given this conclusion, the crucial example in Babyonyshev et al.,(8b), does not provide an argument for covert A- 
movement. It is unacceptable due to the confluence of four non-syntactic factors: marked verb-initial word order, an animate theme with a modal biased towards volitionality, and a mismatch between the semantics of the perfective verb and the unmarked interpretation of the genitive of negation.

\subsection{Coordination}

Even if we accept the judgments given in Babyonyshev et al., there are independent arguments against covert A-movement in unaccusatives. The first comes from coordination. Two infinitival clauses each containing a genitive of negation, bracketed in (15), can be coordinated under a single raising verb.

$$
\begin{aligned}
& \text { pora priznat' čto ne možet } \\
& \text { time admit.INF that not can.3sG } \\
& \text { [pojavit'sja nov-yx } \quad \text { idej] } \\
& \begin{array}{lllll} 
& & & \\
\text { appear.INF new-GEN.PL idea.GEN.PL or } & \text { increase.INF inspiration-GEN }
\end{array}
\end{aligned}
$$

'It is time to admit that new ideas cannot appear or inspiration cannot increase.'

This should be impossible because both GNs could not undergo covert A-movement to the matrix subject position. Moving either one alone would violate the Coordinate Structure Constraint. ${ }^{6}$ Moving both XPs in an across-the-board (ATB)-like derivation would also be illicit because ATB movement must apply to the same constituent in both conjuncts (Ross 1967, Williams 1978, and others). Franks 1995 shows that morphological identity is in fact required in Russian ATB movement. Such movement would also target one landing site, spec,TP, with two distinct constituents. Bošković and

\footnotetext{
${ }^{6}$ See Lin 2001 for evidence that A-movement is subject to CSC effects.
} 
Franks 2000 argues that covert ATB movement does not exist, which would independently rule out such a derivation.

\subsection{Long-distance scrambling}

A second argument comes from scrambling. Russian has long-distance scrambling of arguments and some adjuncts, typically in colloquial, spoken registers (Bailyn 2001, Testelets 2006, and others):

$$
\begin{array}{llllll}
\text { ja mašin-u xotel } & \text { [čtoby } & \text { oni kupili mašin-u } \mathrm{v} & \text { Moskve] } \\
\text { 1SG car-ACC wanted } & \text { COMP.SBJV they bought } & \text { in Moscow }
\end{array}
$$

'I wanted them to buy a car in Moscow.'

Such scrambling, however, is not acceptable for subjects under normal intonation (Bailyn 2001, Testelets 2006, Glushan 2006), (17). ${ }^{7}$

$$
\begin{aligned}
& \text { *Petja mne xočetsja [čtoby Petja zašol] } \\
& \text { Petya me want COMP.SBJV Petya stopped_by } \\
& \text { ('Petya I want to stop by.') }
\end{aligned}
$$

This also holds for passive subjects and dative subjects and, thus, is not tied to a particular surface case form. Bailyn (2001:647) proposes that Russian long-distance

\footnotetext{
${ }^{7}$ Müller and Sternefeld 1993, based on Zemskaja 1973, give several examples of longdistance scrambling of subjects, including scrambling out of an adjunct clause; however, these examples all involve questions and are unacceptable without a strong intonation break before and after the scrambled DP.
} 
scrambling is $\mathrm{A}^{\prime}$ movement and that the subject-object asymmetry follows from the thattrace effect, which is independently attested in Russian.

If the GN theme of an unaccusative verb undergoes covert movement to the subject position, we expect that it should be barred from long-distance scrambling. There are two scenarios to consider: If the GN theme were to undergo early A-movement to spec, TP as part of the scrambling derivation, this would result in an illicit extraction from subject position, on par with (17) above. On the other hand, if the GN theme were to scramble directly from object position, without stopping in spec, TP, it would be licit from a long-distance scrambling perspective but would violate whatever forces the covert Amovement to spec, TP. However, the GN theme of an unaccusative verb turns out to successfully undergo long-distance scrambling, (18a), just as objects do. Compare that to the unacceptability of such scrambling with a nominative subject, (18b). We conclude that scrambling restrictions also argue against covert A-movement.

(18) a. xuliganov mne xočetsja [čtoby zdes' ne pojavljalos' xuliganov] hooligan.GEN.PL me want COMP.SBJV here not appeared.3SG.NTR 'I want no hooligans to appear here.'

b. *xuligany mne xočetsja [čtoby zdes'ne pojavljalis' xuligany] hooligan.NOM.PL me want COMP.SBJVhere not appeared.3PL

\subsection{Scope}

A final argument comes from scope considerations. Russian subjects interact scopally with clausemate negation. The following example illustrates the resulting ambiguity: 


$$
\begin{array}{llll}
\text { vse } & \text { obidy } & \text { ne } & \text { zabyvajutsja } \\
\text { all.NOM } & \text { hurts.NOM } & \text { not } & \text { be forgotten.3PL }
\end{array}
$$

'All hurts do not disappear from memory.' $\quad$ ALL $>$ NEG, NEG $>$ ALL

Assuming that the GN theme of an unaccusative verb undergoes covert movement to the subject position, we expect to see the same ambiguity. The example in (20) should have the same two interpretations as in (19) because it will have an LF in (20b) identical in structure to (19). This expectation is not borne out however. (20) is unambiguous and allows only the reading in which negation scopes over the GN theme, as would be expected from an LF in which there is no A-movement, $(20 \mathrm{c}) .^{8}$

(20) a. na sobranii ne prisutstvovalo vsex sotrudnikov on meeting not be_present.PAST.NTR [all employee].GEN.PL 'Not all employees were present at the meeting.' *‘All employees were not present at the meeting.' *ALL $>$ NEG b. all employee not [be present] COVERT A-MOVEMENT LF c. not [be present all employee] NO MOVEMENT

\footnotetext{
${ }^{8}$ The low scope behavior of GN is well known (see Harves 2002 for an overview and references therein). A number of researchers account for this pattern (Pesetsky 1982, Brown 1999, Pereltsvaig 1999, Harves 2002, Kagan 2007) but they do not simultaneously raise the GN above negation, either overtly or covertly.
} 


\section{Conclusions}

Based on the categorical evidence from coordination, scrambling, and scope as well as on the graded judgments on the crucial supporting examples - which vary with word order, aspect, and animacy — we conclude that the proposal that Russian unaccusatives involve covert A-movement is incorrect. While covert A-movement may exist, it is not found in Russian unaccusative structures. If this is correct, two important questions arise for future research. First, what is the correct syntax for Russian unaccusatives with or without GN themes? The central theoretical issue is the status of the EPP and spec,TP in Russian. Second, what accounts for the acquisition patterns reported in Babyonyshev et al.? It was shown there that children have difficulty with unaccusative verbs that allow or require a GN theme. The explanation given in Babyonyshev et al. is that children have difficulty with the required A-chain because such children do not yet represent A-chains in their grammars. Given that unaccusative verbs with GN themes do not involve A-movement, covert or overt, that explanation for the acquisition data will need to be rethought.

\section{References}

Babby, Leonard. 1975. Impersonal verbs and their lexical specification. Slavic and East European Journal 19, 182-187.

Babby, Leonard. 1980. Existential sentences and negation in Russian. Ann Arbor: Karoma.

Babyonyshev, Maria, Jennifer Ganger, David Pesetsky, and Ken Wexler. 2001. The maturation of grammatical principles: Evidence from Russian unaccusatives. Linguistic Inquiry 32,1-43.

Bailyn, John. 2001. On scrambling: A reply to Bošković and Takahashi. Linguistic Inquiry 32, 635-658. 
Benigni, Valentina. 2006. Declino della cooccorrenza di genitivo e accusativo nell'espressione dell'oggetto diretto in russo. Studi italiani di linguistica teorica e applicata 35, 505-547.

Bošković, Željko, and Steven Franks. 2000. Across the board movement and LF. Syntax 3, 107-128.

Brown, Sue. 1999. The syntax of negation in Russian: A minimalist approach. Stanford: CSLI.

Burzio, Luigi. 1986. Italian syntax. Dordrecht: Reidel.

Chvany, Katherine. 1975. On the Syntax of BE-Sentences in Russian. Bloomington: Slavica.

Comrie, Bernard. 1976. Aspect. Cambridge: Cambridge University Press.

Dowty, David. 1991. Thematic proto-roles and argument selection. Language 67, 547619.

Filip, Hana. 1999. Aspect, eventuality types, and nominal reference. New York and London: Garland.

Franks, Steven. 1995. Parameters of Slavic morphosyntax. Oxford: Oxford University Press.

Glushan, Zhanna. 2006. Japanese style scrambling in Russian: Myth and reality. Master's thesis, University of Tromsoe.

Harves, Stephanie. 2002. Unaccusative syntax in Russian. Ph.D. dissertation, Princeton University.

Huang, C.-T. James. 1982. Logical relations in Chinese and the theory of grammar. Ph.D. dissertation, MIT.

Kagan, Olga. 2007. On the semantics of structural case. Ph.D. dissertation, Hebrew University. 
Keller, Frank. 2001. Experimental evidence for constraint competition in gapping constructions. In Gereon Müller and Wolfgang Sternefeld (eds.). Competition in syntax, 211-248. Berlin: Mouton de Gruyter.

Levin, Beth, and Malka Rappaport Hovav. 1995. Unacusativity: At the syntax-lexical semantics interface. Cambridge, Ma.: MIT Press.

Lin, Vivian. 2001. A way to undo A-movement. In Karine Megerdoomian and Leora A. Bar-el (eds.). WCCFL 20 Proceedings, 358-371. Somerville, Ma.: Cascadilla Press.

Mahajan, Anoop. 1990. The A/A-bar distinction and movement theory. Ph.D. dissertation, MIT.

May, Robert. 1985. Logical form: Its structure and derivation. Cambridge, Ma.: MIT Press.

Müller, Gereon, and Wolfgang Sternefeld. 1993. Improper movement and unambiguous binding. Linguistic Inquiry 41, 35-82.

Partee, Barbara H. and Vladimir Borschev. 2002. Genitive of negation and scope of negation in Russian existential sentences. In Formal Approaches to Slavic Linguistics: The Ann Arbor Meeting 2001 (FASL 10), 181-200. Ann Arbor: Michigan Slavic Publications.

Partee, Barbara and Vladimir Borschev. 2007. Existential sentences, BE, and the Genitive of Negation in Russian. In Ileana Comorovski and Klaus von Heusinger (eds.). Existence: Semantics and syntax, 147-190. Dordrecht: Springer.

Pereltsvaig, Asya. 1999. The genitive of negation and aspect in Russian. McGill Working Papers on Linguistics 14, 111-140.

Perlmutter, David. 1978. Impersonal passives and the unaccusative hypothesis. Berkeley Linguistic Society 4, 157-189. 
Perlmutter, David. 1983. Personal vs. impersonal constructions. Natural Language and Linguistic Theory 1, 141-200.

Pesetsky, David. 1982. Paths and categories. Ph.D. dissertation, MIT.

Richards, Norvin. 2001. Movement in language: interactions and architectures. Cambridge, Ma.: MIT Press.

Ross, John. 1967. Constraints on variables in syntax. Ph.D dissertation, MIT.

Testelets, Jakov. 2006. Review of Karimi, ed. On scrambling. Voprosy jazykoznanija 2006, No 4, 121-128.

Williams, Edwin. 1978. Across-the-Board rule application. Linguistic Inquiry 9, 31-43.

Zemskaja, Elena A., ed. 1973. Russkaja razgovornaja reč'. Moscow: Nauka. 